\title{
Scientific Wanderlust Across The Ocean
}

一海の向こうからの研究放浪記，オランダから日本へ一

\author{
福井大学 Willem Van Rooijen
}

\begin{abstract}
1999 年の夏, デルフト工科大学の学生として日本の研究機関や企業を見学しに来日した。そ してその最初の東京の数時間で私の人生が変わった。卒業後, 日本に職を求めるのは簡単では なく，しばらく米国ジョージア工科大学で働いたあと再来日を果たし 10 年になる。はじめ日 本の文化はヨーロッパや米国に似て分かりやすいと思ったりしたが，日本はやはり基本的に ヨーロッパとは異なる。自分の生まれ育ったヨーロッパ文化のフィルターを完全に消し去るこ とはできないが，「外部観察者」でいることにもまたメリットがある。私の日本での日々と思い を「外部観察者」の目から綴ってみたい。
\end{abstract}

\section{KEYWORDS: The Netherlands, cultural differences, approaches to problem solving, safety culture}

\section{I .はじめに一日本との出会い}

最初に日本に来たのは, 1999 年の夏, オランダのデル フト工科大学応用物理学科の 4 年生の時であった。私た ちは学生 28 人で日本における「応用物理学」の研究機関 と会社を見学しにやって来た。成田空港に着陸して, そ れから電車で東京まで。初めて日本の景色を見て大変な 「ショック」を受けた。当惑した。私の出身地のオランダ では, 全てがきちんと整理されている。畑は四角, 道は 真っすぐ，景色はどこでも「平」，住宅は全て一緒。それ で, 日本は…完全な混乱！うっとりとした。10 時間の飛 行で結構疲れていたし, 成田から東京まで 1 時間は超え たと思うが，電車の窓からずっと景色を見ているうち に，列車はくねくねと蛇みたいに東京の中心の上野駅ま で行った。私たちは地下鉄の銀座線に乗り換えて, 最後 にホテルまで歩いた。東京は梅雨の季節で，これまでの 人生で見たこともない大雨。ホテルのロビーに着いた ら，みな口々に「暑い!」「こんな雨は信じられん!」「も ういや!」。でも私は，道を見ながら，「ここって本当に 魅惑的だな」と思った。あの最初の東京の数時間で人生 が変わった。

オランダに帰国したあと, ライデン大学と東京にある 日蘭学会の 1 年間の交流プログラム「Japan Prizewinners Programme（JPP)」に申請した。JPP で初めて日本語を 勉強したが, これは魅力的な経験になった。高校生時代

Scientific Wanderlust Across The Ocean; From the Netherlands to Japan : Willem Van Rooijen.

(2018 年 2 月 5 日 受理), (原文日本語)

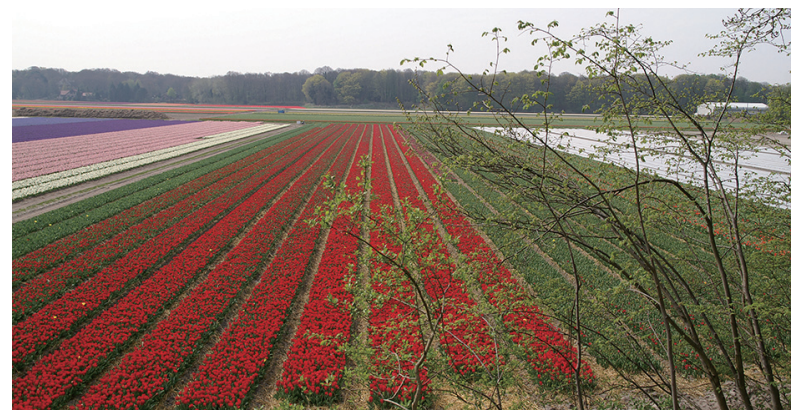

図 1 オランダのチューリップ畑

の一番好きな課目は古典ラテン語と古典ギリシア語で, その他に, オランダ語, 英語, フランス語, ドイツ語とロ シア語を勉強した。文法，構文，語族，語源，形態論。 ヨーロッパの言語は，語族から見るとよく似ているので, 文法などはほぼ一緒である。フランス語を読めるなら， イタリア語とスペイン語もある程度理解できる。日本語 は全く異なった!それまでに勉強した言語と全く関係が なかった。だから言葉をすべて「暗記」しないといけな かった。文字はアルファベットと全く異なっていた。漢 字, ひらがな, カタカナの書き方は，「完全な一貫性」と同 時に「完全な混乱」。本語の勉強は完全な「新たな経験」 となった。

JPP でつくば市の産業技術総合研究所でロボットの音 声認識関係で 7ケ月研修した。産総研の指導官はバイク を持っていて，そのバイクを使わせてくれた。そうする と，この世の中の一番好きなことが結びついた：「日本」 と「バイク」。バイクでどこまでも行った。福島県の会津 若松, 日光, 富士山, 飛騨高山, 仙台…JPP で日本語を 


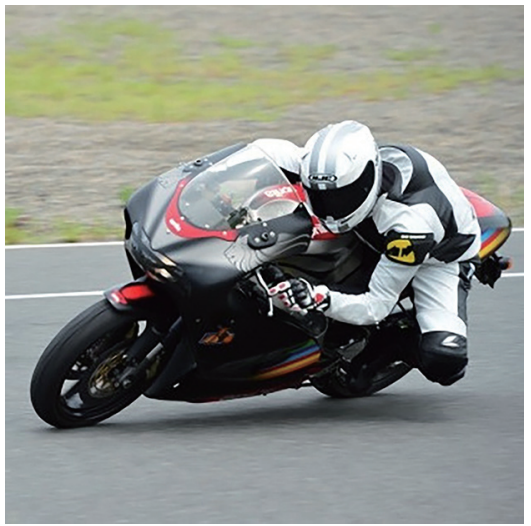

図 2 バイクに乗る筆者

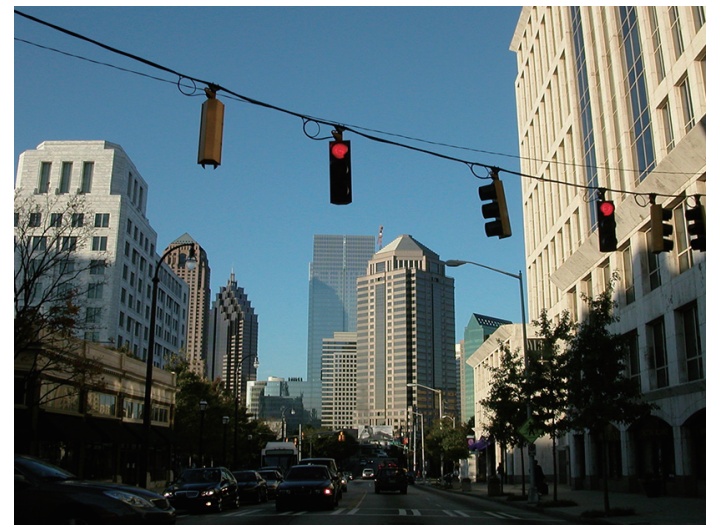

図 3 ジョージア工大のあるアトラン夕市街
勉強したので, 少なくとも, 少し日本語を話せて, 旅行 でたいへん役に立った。

JPP の 1 年間が終了してから, オランダに帰国し，デ ルフト工科大学の原子炉研究所と応用物理学科の原子炉 物理学部門のドクターコースに入学した。博士論文は第 4 世代高温ガス炉の核燃料サイクルだった。卒業の 1 年 前から，日本のポスドクを探したが，何とも上手く行か ず, 結局, 米国ジョージア州アトランタ市にある「ジョー ジア工科大学」の原子力専攻に助教として就職した。ア メリカの仕事は面白かったけど，日本にまた戻りたかっ た。2008 年の 2 月に福井市で開催された国際会議に出 席したら, 以前にメールで相談にのってくれた福井大学 の望月教授と会った。望月先生が 2009 年度から発足す る予定の「附属国際原子力工学研究所」について説明して くれ，その瞬間，アメリカの仕事を止めて福井大学に転 職することにした。結局, 2009 年の 6 月から, 日本原子 力研究開発機構の「特別研究員」と福井大学の「研究員」と して，また日本にやって来た。

\section{II. 文化のフィルターについて}

自分の文化と異なる環境で生活すると, 奇妙な経験を することになる。新しい環境に入ってしばらくすると, 新しい環境を理解できたと思い始める。が，実際には新 しい環境の基本はまだ理解できていない。新しい環境の 理解にはやはり長い時間がかかる。でもその結果, 「日 本」という国の文化は，表面的に「ヨーロッパまたは米国 の文化」に似ていると思い, 外国人として「分かりやすい 環境」であると判断してしまう。しかし，実際の日本文 化は非常に分かりづらいと思う。日本の文化はやっぱり 「基本的に」ヨーロッパと違う。

「新しい文化」を勉強すると，「自分の文化」の勉強にも なる。私の場合,「オランダの考え方」と「日本の考え方」 の違いが問題となる。そういう場合，「正しい」考え方が あるのか? 深い理解のために, その二つの考え方（哲学 とも言える)が違う理由と原因を説明しないといけない ので, 自分の文化と新しい文化の両方を評価する必要が
ある。そして, 新しい文化の勉強は大変時間のかかる仕 事になる。私の場合, 毎日, 日本について勉強して, も うそろそろ 10 年になる。

われわれ人間には，この世の中における出来事の原 因, 理由, それからその意味の解析のために「文化のフィ ルター」が備わっている。科学者, 工学者として, 自分の ことを「合理的」であると思っているが，「合理的」の意味 も, 文化によって異なる。人間として, 自分の文化の フィルターの影響を完全に消し去ることは非常に難し い。たぶんそれは不可能である。一方で, 多少奇妙に聞 こえるが「外部観察者」でいることにはメリットがある。 「外部観察者」はその地の文化的背景を持たないからだ。

文化のフィルターに関して,一つの例を紹介したい。 私の一番好きな日本の映画は伊丹十三監督の「タンポポ」 である。表面的には「タンポポ」は「ラーメンの映画」であ るが, 実は日本の社会に対する非常に微妙な風刺でもあ る。そういう微妙な風刺性は, 日本人にとっては当たり 前のことだから，あまり気づかないと思う。文化のフィ ルターの影響で，日本人にはそういう「当たり前のこと」 の珍しさが見えず，理解できないのではないだろうか。

\section{III. 原子力安全の文化}

原子力安全文化にとって「外部観察者」的観点の重要性 に異論の余地はない。安全基準の国際的なピアレヴュー が強調される理由である。福井大学に来てそろそろ 10 年になる。この期間にフクシマの事故があって, 事故に 伴う様々な議論に接した。ここで,「外部観察者」として 原子力の安全文化に関する私の意見を紹介したい。下記 に紹介することは日本の専門家の皆さんにもよく分かる と思うが, その安全文化への影響は往々にして過小評価 される。

まず，「問題解決への日本型アプローチ」について。こ こで, 日本の文化を, 私に経験があるヨーロッパおよび 米国の文化と比較する。単純に言えば, 日本人は「処理・ 方法」に向かい, ヨーロッパ人は「目的」に向かい, 米国人 は「結果」に向かう。これを私の好きなバイクにあてはめ 
るなら, 日本人の工学者は「このバイクはどうすれば作れ るのか」(過程), ヨーロッパ人の工学者は「どういうバイ クを作るべきか」(構想), それから米国人の工学者は「ど ういうバイクを作れば利益が出るか」(結果)を考える。

構想, 過程, 結果は 3 問とも重要であり, 成功する「も のつくり」のためには 3 問とも解答しないといけない。 ここで説明したいのは，問題の順番である。日本の文化 では「処理過程・方法」が第一となるので, 他の問題が忘 れられる恐れがある。日本人の考え方は科学分野でも確 認できる。日本人が書く論文の表題には「・.手法開

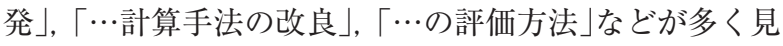
られる。伝統的な日本の茶道も非常に目立つ例である。 茶道の目的は，あくまでも搽であるけれど，茶道では 「正しい技茶の入れ方」は結果よりも重要である。

原子力ではどうか。原子力規制の枠組みでは「处理・ 方法」への集中により，「規制の目的」よりも，「規制の方 法」に終始する恐れがある。規制において，「查察方法」 では考慮されていない不安全な状態を見逃す恐れがあ る。その他に, 不安全な状況についての組織的な知識ま た個人的な知識があっても, 查察方法のみを遵守して評 価した結果，問題を見逃してしまう恐れがある。

\section{IV. 誤りのタブー}

第 2 の日本の文化の特徴として,「誤りのタブー」があ る。日本人は危険回避行動で生きている。この特徽に関 しては, メリットとデメリットがある。例えば，授業中 に学生に質問しても，返事が間違っていると恥ずかしい と思うためか, 誰も返事してくれない。学生は海外の研 究者などとあまり話さない。英語での会話に自信がない ため, 間違っていると大変だ，何も言わないほうがいい と思うのだろう。オランダでは，そういう「非コミュニ ケーション」は，特に「上司」から声をかけられた場合な ど, 非常に失礼である。日本社会では,「非コミュニケー ション」の失礼よりもまず「誤りのタブー」を恐れる。

「誤りのタブー」の最大の問題は「誤りの告白」が非常に 難しくなることである。原子力安全のためには, 安全基 準を最新の知識に基づいて改良し，施設を遲滞なく基準 に適合させ，その経緯を常に公知するサイクルを回すこ とが常識でありまた必須でもある。ところが日本では 「基準の改訂」や「施設の改善」が,「何か問題があった」と いうことだと評価され，その結果このサイクルが著しく 遅れる。「社会」の責任も指摘させて頂きたい。合理的な 社会において, 誤りや不正について合理的に議論し, 合 理的に解決するべきである。そうしないと，問題が過小 評価されてしまい，非常に危険な状況になる恐れがある。

\section{V. 個人の独立}

第 3 の日本の文化の特徵として指摘したいのは,「独 立性の欠如」である。特にヨーロッパの文化と比べたら，
日本の文化で「独立性」はあまり評価されない。ここで， 「独立性」の意味は，「個人的な責任」になる。オランダの 大学院生の時に,「鉄道の安全文化」についての講義が あった。先生は鉄道の工事の安全確保の専門家だった。 先生の説明によると, 工事の労働者の安全確保の責任は 必ず 1 人。 2 人や 3 人は絶対ダメだと言われた。理由と して, (1) 安全確保に複数の担当者がいると, 担当者同士 が互いの判断を信じて, 何か不安全な状態になっても, お互いの反応を待ってしまい, 対応が遅れる可能性が大 きくなる。(2) 1 人の担当者が不安全な状態を確認して も, 2 人目が反応しないと, 問題がないと思ってしまう。 （3）もし事故になったら，安全性の担当者の個人的な責 任を確認できなくなる。私は個人的にちょっと納得でき ないところもあるが, オランダの安全文化の基本は「1人 の責任」である。

日本の文化では, 「皆の協力が一番有効」,「グループは 個人より強い」, 「2 人の知恵が 1 人の知恵より大きい」と 考える。昔の原子力規制は, 原子力を推進する経産省の 分担だった。実は，そういう「独立性の少ない」状態にも 色々メリットがある。メーカーや電力会社か困っている ところ等は非常に早く解決できる。しかし, 福島の事故 で日本の安全文化の考元方の弱点が明らかになってし まった。厳しい判断であればあるほど，多くの担当者が いるせいで，担当者がお互いの判断を待ってしまう。

\section{VI. 日本の大学とその研究環境について}

これまで 26 人の日本人がノーベル賞を受賞した。こ のうち, 14 人が最近の 10 年の受賞で,「ハードサイエン 久」(物理学, 数学, 天文学, 化学, 生物学等) が 11 人を占 める。受賞した日本人の専門は物理学, 化学, 医学だっ た。ノーベル賞の実績からみると, 日本の研究環境は世 界水準にあることは間違いない。しかし，ノーベル賞研 究は「歴史的な研究の成果」でもあるので, 将来を保証し てくれるものではない。

他の先進国と比べたら，日本の第 3 期の教育レベルは 高い(第 3 期教育 : 高校などの中等教育を終えた人を対 象とした教育段階)。OECD の統計を用いて確認したと ころ,「第 3 期教育達成率」は日本が世界で 3 番目になる (韓国とカナダは 1 番， 2 番である)。しかし，日本の大 学院レベルの教育には大きな問題がある。「学生教育負 担」(学生として教育のために払わないといけない金額) は世界で一番高く, 進学(博士前期課程, 博士後期課程と 共に)の達成率は最悪の順になっている。100万人の人 口当たり，日本に「博士」は 135 人(うち「ハードサイエン ス $\rfloor 55$ 人)しかいない。韓国：100 万人当たり 193 人，イ ギリス: 272 人, ドイッ $: 290$ 人。日本人の物理学の博士 の 1 人に対し，ドイツには 2 人がいることになる。この 点でも研究開発分野の未来には大きな不安を抱えている。 将来に向けて, 博士後期課程の人材を増やすべきで, 
才能ある学生に対して, 進学を勧めるべきであると思 う。複数の改良方法があるだろう。その 1 つは，アメリ カの「Graduate Research Assistant」制度と同様に大学院 生に毎月の給料を支給するといい。「大学院生給料制度」 は 2 つの大きなメリットがある。第 1 は, 学生への負担 を軽減し，アルバイトなどはしなくてもいい状態にな り，研究に集中できるようになる。第 2 は能力の足りな い学生は進学できなくなり（業績のない学生に誰も抒金 払いたくないわけ), 大学院生の平均水準が高まる。も う 1 つ改良できるところは, 博士で卒業した社員と研究 員の給料を増やすべきであると思う。

\section{VII. 日本のものつくり}

「ものつくり」は日本経済の要であるが, 同様な商品を 安く提供できる相手が出てきている。韓国と中国の自動 車メーカーが市場に入り，日本のメーカーとほぼ同じ商 品を半分の值段で提供できれば，非常に厳しい状態にな る。携帯電話, パソコン, 半導体のデジタル製品の市場 では，外国のメーカーとの競争が激しく，利益幅は非常 に少なくなっている。さらに，日本における社会の高齢 化を考えるなら, 将来に向け労働者の生産性の高度化が 必要になる。高度の教育を受けた人材に基に利益幅の大 きい「この世の中にまだない商品を開発しないといけな いと思うが，現在の日本のメーカーが必要とする「イノ ベーションの力」はまだない。

すでに書いた日本の文化の特徴も災いして，日本の メーカーは投資を先延ばしする傾向がある。自分の研究 開発よりも, 米国, ヨーロッパのメーカーの研究開発と 商品を勉強して，それから一番成功できると思われる技 術を選択する。この行動は(部分的に)危険回避行動であ る。ほぼ完全にできている技術を選択すると失敗の確率 は小さくなる。

日本のメーカーのやり方は時には有効である。リスク を少なくし，研究開発の予算もあまり必要ないのに高品 質の製品を提供できる。一方，デメリットとして，新商 品の市場参入は遅れ, 「最新」,「最先端」の商品を提供で きなくなってしまう。日本のメーカーの市場参入は，第

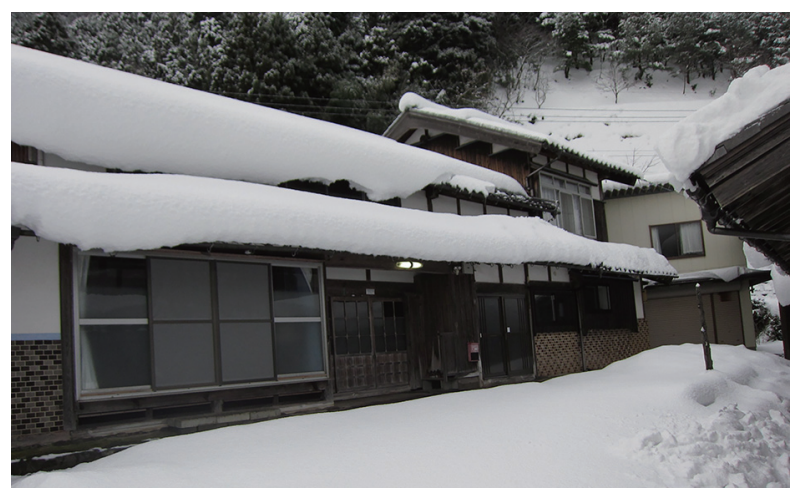

図 4 筆者の住む古民家
2 番目, 第 3 番目になる場合が多い。最先端の商品を提 供できないと利益幅の大きい商品が提供できない。

\section{VIII. 日本での暮らし}

2009 年に日本に来た時は 1 年契約で来た。その 1 年 契約は毎年延長が必要だったので, じっくり基本を作る ことがあまりできなかった。しかしその後, 福井大学の 教員の募集があったので応募し，任期なしで採用された ときは本当に嬉しかった。仕事が安定したから，基本を 伸ばすことができた。

一方私生活では福井県嶺南地方の集落にある古民家を 買った。嶺南地方には，「空き家問題」があり，私が購入 した古民家も空き家状態だった。日本の高齢化と少子化 は嶺南地方でも大きな問題になっている。平均年齢が 60 歳を超える集落が多い。高齢化は問題でもあるが, 好 機でもあると思う。日本人は「実家」または「実家の土地」 を売りたくないので，空き家状態の家はどんどん増えて いる。でも，集落の生活には色々なメリットもある。子 育てのいい環境にもなるし，物価が低い。例えば，長期 間利用契約を結んで，空き家状態になった家を若者の家 族に使ってもらうといい。家の解体補助金も考えられ る。空き家になった建屋を解体して木を植え, 動物と植 物に優しい環境つくりもできる。場合によって, 利益を 取れる果樹園なども考えられる。最後に, 利用されてい ない田んぼの長期間リースなども考えられる。長期間 リースにより，田んほを有効に利用して頂き，農業の雇 用の機会にもなると思う。

\section{X. おわりに}

日本の高齢化と共に, 労働生産性を継続的に増やさな いといけない。労働者の生産性向上は, 機械と多量の工 ネルギーを必要とするので, 安定したエネルギー資源, 競争価格のエネルギー資源が必要になる。私の意見で は，この条件を満たすエネルギー資源は「原子力」しかな い。東日本大震災の前の自信を取り戻し, 将来に向けて の日本の原子力産業界の再活性化に期待している。

私は「日本」というところが好きなので，福井大学の仕 事に精を出し, 集落の生活を楽しみながら, 私の小さな 力で周りの人の生活に貢献できるといいと思っている。

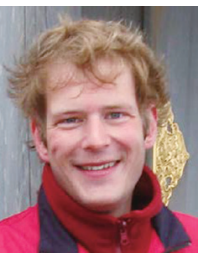

著者紹介

Willem Van Rooijen（ウィレム・ファ ン・ローイエン)

福井大学付属国際原子力工学研究所 (専門分野/関心分野) 原子炬の数值解析, 核燃料サイクル評価, 原子炉設計, 新型炉 